\title{
Dijital Çağda Paranın Dönüşümü: Kripto Para Birimleri ve Blok Zinciri (Blockchain) Teknolojisi: Üniversite Öğrencilerine Yönelik Bir Araştırma
}

\section{Transformation of Money in Digital Age: Crypto Currency and Blockchain Technology: A Research for University Students}

Şeyhmus Doğan a,*

${ }^{a}$ Dr. Öğr. Üyesi, Niğde Ömer Halisdemir Üniversitesi, İletişim Fakültesi, Halkla İlişkiler ve Reklamcılık Bölümü, 51240, Niğde/Türkiye ORCID: 0000-0002-5993-0363

\section{MAKALE BİLGİSi}

\section{Makale Geçmişi:}

Başvuru tarihi: 14 Kasım 2019

Düzeltme tarihi: 03 Subat 2020

Kabul tarihi: 25 Şubat 2020

Anahtar Kelimeler:

Kriptografik Varlık

Kripto Para

Dijital Para Birimi

Altcoin

Blok zinciri Teknolojisi

\section{A R T ICLE INFO}

\section{Article history:}

Received 14 November 2019

Received in revised form 03 February 2020

Accepted 25 February 2020

\section{Keywords:}

Cryptographic Asset

Crypto Currency

Digital Currency

Altcoin

Block chain technology
ÖZ

Dijital para birimleri olan kripto paralar ve kripto paraların dayandığ temel sistem olan blok zinciri teknolojisi, son yıllarda medyadan, finans endüstrisinden, araştırmacılardan, hükümetlerden, düzenleyici kurumlardan ve yatırımcılardan büyük ilgi görmektedir. Bu ilginin kaynağını, teknolojik yeniliklerin ve özellikle de dijitalleşmenin para kavramını ve paranın yapısını nasıl etkilediğinin belirleyicisi olan, teknoloji ve ekonominin kesişiminde görmekteyiz. Bu bağlamda bu çalışma, kripto paralar ve blockchain teknolojisi hakkında bilgi vermek ve Niğde Ömer Halisdemir Üniversitesi öğrencilerinin kripto para birimlerini bilme ve kullanım düzeylerini tespit etme amacına yönelik olarak yapılmıştır. 400 öğrenciye uygulanan anket sonucunda elde edilen veriler, SPSS 15 programında sayısallaştırılmış, yapılan analizlerde üniversite öğrencilerinin kripto para birimlerinden haberdar oldukları, ancak öğrenciler arasında kripto para kullanım düzeyinin düşük olduğu sonucuna varılmıştır.

\section{A B S T R A C T}

Crypto currencies, each of which is a digital currency, and block chain technology, which is the basic system on which crypto currencies are based, have received great attention from the media, financial industry, researchers, governments, regulatory agencies and investors in recent years. In this context, this study is aimed to give information about crypto currency and blockchain technology and to determine the level of usage and knowledge of crypto currencies of Niğde Ömer Halisdemir University students. The data obtained from the questionnaire applied to 400 students were digitized in SPSS 15 program and it was concluded that university students were aware of crypto currencies, but the level of crypto money usage among students was low.

\section{Giriş}

Para, bir değer deposu, bir hesap birimi ya da doğrulanabilir bir kayıt midır? Yoksa bir değiş-tokuş aracı olarak insanı hedeflerine ulaştıracak, kişiyi bir noktadan başka bir noktaya taşıyacak, hayallerine ulaştıracak bir araç mı, yoksa mutluluk mudur; kullanmak mı yoksa yığmak mı gerekir parayı, paranın efendisi olmak mi yoksa paraya hizmet etmek mi gerekir, dünyayı döndüren(!) şey para mıdır? Bu sorular çoğaltılabilir; ancak paranın neye yaradığ 1 ; neden, ne için istendiği net olarak tespit edilirse, onun sadece hizmet edecek ve yönetilmesi gereken bir araç olduğu anlaşılabilir. Günümüzde paranın felsefi sorularına ek olarak tüm dünyada evrimine yönelik ciddi sorular sorulmaya başlanmıştır; çünkü dijital çağ olarak adlandırdığımız, içinde bulunduğumuz bu dönemde yaşam biçiminden, örgütlenmeye; eğitimden paraya kadar birçok unsurun kabuk değiștirdiği görülmektedir. Böyle bir ortamda bugün, özellikle de paranın türüne ve yapısına yönelik sorular

\footnotetext{
* Sorumlu yazar/Corresponding author.

e-posta: seyhmusdogan@hotmail.com
} 
çoğunluktadır. Mal para, temsili (kıymetli madenlere çevrilebilen) para, kâğıt para, kaydi para, sertifika para, plastik (kredi kartı) para vb. var olan para türlerinin uzun zamandır yaygın olarak kullanılanları arasındadır. Bugün para ile ilgili tüm dünyada sorulan en büyük soru ise paranın türüne yönelik "hangi para" sorusudur.

Bilişim teknolojilerinin mümkün kıldığı küresel yapının son on yıldaki en etkili çıktılarından biri de kripto paralar olmuştur. İletişimin şeklini değiştiren (reform) dijital bilgi teknolojileri, paranın tanımını, yapısını değiştirecek ölçüde yeni bir olgunun da önünü açmıştır. İletişimin küresel çapta bu denli kolay ve hızlı yapıldığı bir dönemde maddi varlıkların dijital olarak transfer edilebilmesi, alınıp satılabilmesi için yeterli teknolojik alt yapı oluşmuşken bu firsatın imkâna dönüştürülmesi gerekliliği ortaya çıkmıştır. Bunu yapan da blockchain denilen teknolojik alt yapıyı kullanan kripto paralar olmuştur (Polat ve Akbıyık, 2019: 445). Gelişmeler, son 15-20 yıla damgasını vuran dijital sosyal ağların iletişim alanında yaptığı hızlı ve köklü değişikliklerin benzerini, son 10 yılda dünya gündeminde yer edinen kripto para ve onun temel dayanağı olan blockchain teknolojisinin finans alanında yapma potansiyeline sahip olduğunu göstermektedir.

Son on yılda, teknoloji ve bilgisayar gücündeki gelişmelerle desteklenen finansal alan ve araçlarda bir dijital devrim dalgası görülmektedir. Bu dijital yeniliğin öncüsü (Munoz vd., 2018: 4), "başlangıçta şirketler tarafindan yatırım amaçl para toplamak için kullanılan ve "dijital jetonlar" (digital tokens) olarak adlandırllan bir değişim aracı olarak kullanılmak üzere tasarlanmış Bitcoin gibi kripto varlıklarının ortaya çıkışıdır". Küresel düzeydeki etkileri henüz çok belirleyici seviyede olmasa da kripto paraların sınır ötesi işlemler açısından önemi her geçen gün artmaktadır. Kripto para birimleri, uzun süredir devam eden ve değişmeyen finansal ödeme sistemlerine alternatif olarak ortaya çıkan bir teknolojik para ya da elektronik paradır. Kripto para birimleri, geleneksel paranın ve normatif ulusal para birimlerinin yerini tamamen alamayacak olsa da internete bağlı küresel pazarların ve dijital transfer taraflarının birbirleriyle etkileşim ve alışveriş biçimini değiştirebilmiştir.

Bu makale kripto para kavramına genel bir bakış sağlamakta olup şu şekilde düzenlenmiştir: Öncelikle kripto paraları anlamak için temel kavramlar açıklanmıştır. Ardından kripto para ve altcoin kavramları ile blok zinciri (blockchain) teknolojisi açıklanmış, devamında şu an için kripto paraların sahip olduğu handikaplara, temel zorluklara odaklanılmış ve eleştirilerde bulunulmuştur. Araştırma bölümünde ise; dijital para birimleri ve Blockchain teknolojisi çerçevesinde Niğde Ömer Halisdemir Üniversitesi öğrencilerinin kripto para birimlerini bilme ve kullanma düzeyleri nasıldır? Sorusu çerçevesinde elde edilen veriler değerlendirilmiş, geleceğe yönelik analizler için kısa bir tartışma ardından öneriler ile çalışma sona erdirilmiştir.

\section{Kriptografi ve Kripto Varlıklar}

Kriptografi ya da şifreleme, okunabilir durumdaki bir verinin içerdiği bilginin istenmeyen taraflarca anlaşılamayacak bir hale dönüştürülmesinde kullanılan yöntemlerin tümüdür. Kriptografi bir matematiksel yöntemler bütünüdür ve önemli bilgilerin güvenliği için gerekli gizlilik, aslıyla aynilik, kimlik denetimi ve asılsız reddi önleme gibi şartları sağlamak amaçlıdır. Bu yöntemler, bir bilginin iletimi esnasında ve saklanma süresinde karşılaşılabilecek aktif saldırı ya da pasif algılamalardan bilgiyi -dolayısıyla bilginin göndericisi, alıcısı, taşıyıcısı, konu edindiği kişiler ve başka her türlü taraf olabilecek kişilerin çıkarlarını da- koruma amacı gütmektedir ve bir kriptografik sistem, bilgi güvenliğini sağlamak için bir araya getirilmiş birçok küçük yöntemler bütünlüğü olarak görülebilir. Bu yöntemler yapıları itibarı ile üç ana grupta incelenebilirler: anahtarsız şifreleme, gizli anahtarlı şifreleme ve açık anahtarlı şifreleme (Tilborg, 2000: 9; https://tr.wikipedia.org/wiki/Kriptografi, 2019b). Bir örnek ile de açıklanacak olursa; kriptografi ile ilgili 2014 yapımı bir uyarlama sinema filmi olan "The Imitation Game: Enigma-Yapay Oyun: Enigma" filmi ele alındığında; Alman Enigma makinesinin şifresini çözen ilk bilgisayarı, Benedict Cumberbatch'in canlandırdığı kriptoloji uzmanı Alan Turing'in nasıl yarattığını konu edinen bir hikâye ile karşılaşırız. İkinci Dünya Savaşı Nazi Almanyası'nın savaş döneminde güvenli bir şekilde radyo yoluyla iletebildikleri mesajlar müttefikler tarafindan kolayca elde edilirken, karşı/düşman cepheye karşı mesajlar, günlük olarak değişen bir yabancı anahtarla kodlanmış veya şifrelenmiş olduklarından uzun süre anlaşılamamıştır. Alman askerî Enigma makinesinin dayandığ 1 bu sistem, kriptografik şifreleme sistemidir.

Günümüzde veri güvenliği ve iletişimin gizliliğini sağlamak amaciyla kriptografi kullanılmaktadır. Ticaret ve finans alanında temel olarak kriptografi, dijital kanallar üzerinden gerçekleştirilen mali faaliyetlerde kullanıcı gizliliğini ve güvenliğini sağlamak amacıyla kullanılmaktadır. Kriptografi bir tür şifreleme yöntemi, üçüncü taraf düşmanlarına ya da yetkisiz kişi ya da taraflara karşı güvenli bir şekilde bilgi iletme sistemi olarak tanımlanabilir. Kripto varlıklar ise bilgi ve iletişim teknolojilerinin olanakları ile şifreleme ve ă̆ yapılandırmalarındaki gelişmelerle desteklenen malların, hizmetlerin ve varlıkların küresel dönüşümüne dayanmaktadır (IMF, 2016: 5). Kriptografik varlıklar ve temelindeki teknoloji, çeşitli gerçek dünya nesnelerini dijitalleştirmek için firsatlar sunmaktadır. Dijitalleşmenin faydaları (erişim kolaylığı, transfer gibi), belirsiz bir meraktan bir teknolojiye dönüşen bir devrime doğru büyüyen kriptografik varlıklarla sonuçlanmıştır. Kriptografik varlıklar, kopyalanmasını veya çoğaltılmasını yasaklayacak şekilde tasarlanmış, aktarılabilir dijital gösterimlerdir. Kriptografik varlıkların transferini kolaylaştıran sistem bir "blok zincir" (blockchain) veya dağıtılmış muhasebe teknolojisidir (Leopold ve Vollmann, 2018: 1-2). Çeşitli kriptografik varlık alt kümeleri bulunmaktadır. Kriptografik varlıkların henüz yasal bir tanımının ya da sınıflandırmasının olmadığı tespit edilmiştir; ancak şu an paranın işlevlerini yerine getirememekle beraber bir takas aracı olarak, blok zinciri bazlı mal veya hizmetlere erişim sağlama aracı ya da bir kişi veya kuruluş için fon artırma amacıyla kullanılan şifreleme varlıkları olarak değerlendirilebilir.

Kripto varlıklarından oluşan kümenin potansiyel teşkil eden bir alt kümesi olarak; küresel boyutta ortaya çıkan ve blockchain alt yapısına dayanan, fiziksel olmayan ve yalnızca dijital biçimde var olabilecek bir boyutta bulunan, yoğun olarak tartışma ve araştırma konusu olan, önemli bir kriptografik varlık türü ise (dijital/sanal) kripto para birimleridir. 


\section{Kripto Para(lar) ve Blockchain Teknolojisi}

\subsection{Kripto Para}

Dijital bilgi ve iletişim teknolojilerinin yatay hiyerarşisi milyonlarca dolar yatırım gücü olan lisanslı büyük yatırımcılar ile elinde yüz lirası olan sıradan bir internet kullanıcısını aynı platformda bir araya getiren uluslararası kripto-para borsalarında meyvelerini vermiştir. Bugün bu kripto-para borsaları yüz yıldan fazla hizmet vermekte olan büyük borsalarla rekabet edecek düzeyde milyarlarca dolarlık işlem hacimlerine ulaşmıştır (Polat ve Akbıyık, 2019: 445). Dijital takasın, transferin ya da alışverişin kolaylaştırılması için şifreli, eşler arası/uçtan uca bir ağa dayanan kripto para kavramı, ilk olarak on bir y1l önce 2008 yılında Bitcoin'in mucidi Satoshi Nakamoto tarafindan geliştirilmiş bir fikir olarak ortaya çıkmıştır. Böylece kripto paraların tarihi Bitcoin ile başlamıştır.

Bugün, 08 Temmuz 2019 itibariyle, kripto paraların sayıları 2800'ü geçmiştir ve toplam piyasa değerleri 285 milyar dolara, günlük işlem hacimleri en yüksek 68 milyar dolara ve son 300 günlük işlem hacimleri ortalaması ise 19 milyar dolara ulaşmıştır. Dünya kripto para varlığı, 2017 yılının aralık ayında tüm zamanların en yüksek piyasa değerine ulaşmış olup 800 milyar dolara dayanmıştır. 08 Temmuz 2019 tarihi itibariyle Türkiye kripto para toplam piyasa değeri de 336 milyon dolar, Türkiye için günlük işlem hacmi ise 66 milyon dolar seviyesindedir (CoinMarketCap, 2019a). Kripto paraların ilk ve en popüler, aynı zamanda en çok işlem hacmine ve en yüksek borsa değerine sahip olanı Bitcoin'dir. Bitcoin'in 2009'da piyasaya sürülmesinden bu yana, çok sayıda farklı kripto para birimi geliştirilmiştir.

Sanal-dijital paralar olan kripto para birimleri, özel geliştiriciler tarafindan yayınlanan ve kendi hesap birimlerinde belirtilen dijital değerlerin temsilidir (Demertzis ve B. Wolff, 2018: 5). Kripto paralar; taraflar arasında transfer edilebilecek olan değer veya para biriminin dijital gösterimine dayanır ve elektronik olarak elde edilebilir, depolanabilir, erişilebilir ve işlem görebilirler. İşlem yapan taraflar olduğu sürece de çeşitli amaçlar için kullanılabilir dijital para birimleridir. Ayrıca kripto para birimleri, sanal alan dışındaki mal ve hizmetler için ödemelerde kullanımları önemli ölçüde sınırlandırılmış olsa da, gerçek dünya ürünlerine, hizmetlerine, ulusal para birimlerine veya kendi içinde farklı dönüştürülebilirlik seviyelerine sahip dijital değerler olarak da değerlendirilebilir.

Kripto paralar; dijital işlemlerin çeşitli seviyelerde anonimlik ile yapılmasına olanak sağlayan, dijital olarak şifrelenmiş sayı dizilerinden oluşan ve uçtan uca/eşler arası ağlarda işlem gören ve takas ortamında yaygın olarak kullanılan simgelerdir. İçsel ve sınırlı miktarlarından dolayı genellikle "dijital altın" olarak da adlandırılan değerlerdir (Campbell Verduyn, 2018: 285-286).

Kripto para birimleri; kullanıcıların üçüncü taraf gözetimi olmadan, dijital olarak alışveriş yapabildikleri, sayıca sınırlı olan benzersiz hashlar (verilen girdiye özel/biricik üretilen çıktı) oluşturmak için şifreleme algoritmalarına dayanan, bir bilgisayar ağı ile birlikte ișlemleri doğrulayarak, kullanıcıların sanki fiziksel para birimini kullanıyormuş gibi karma alışveriş yapabilmelerini sağlayan değer birimleridir (DeVries, 2016: 12). Kripto paralar, fiziki olarak kullanılamadığı için, altın ya da mücevher gibi gerçek bir değere sahip bir nesne formatında olmayan; ancak değer, talep, güven ve kabul nedeniyle var olan dijital paralar olarak da tanımlanabilir.

Dijital para birimleri olan kripto paraların kurumsallaşması üzerine çalışmalar yapan Nagaraj, Hunter ve Caplain'e göre (2018: 2) de kripto para tanımı şöyledir: Bir blok zincirindeki birimlerin oluşumunu ve dağıtımını düzenlemek için kriptografik tekniklerin kullanıldığ dijital hesap birimleridir. Uygulamada, kripto paralar insanlar için çok şey ifade ediyor: bir yatırım varlığı sınıfı emtialar gibi, altın gibi bir değer deposu, meşru bir değişim aracı, gizli bir değişim yöntemi, değişmez bir hak ve mülkiyet kaydı veya ödül puanları gibi teşvik edici bir mekanizma olarak da tanımlanabilir.

Kriptografik varlıkların yapısı ve onun alt kümesi olan kripto para birimlerinin tanımları ve vaatleri değerlendirildiğinde kripto paraların finansal işlemlere katkı sağlayabileceği noktalar da şu şekilde özetlenebilir:

- İşlem sürelerini ve maliyetlerini azaltabilir,

- Uçtan uca/eşler arası değişimi kolaylaştırabilir,

- Sınır ötesi para transferinde verimliliği sağlayabilir,

- Güvenli ve düşük maliyetli ödeme seçenekleri sunarak finansal katılımı artırabilir,

- Hızlı, doğru ve güvenli bir finansal kayıt tutulabilmesini sağlayabilir.

Kripto para birimlerinin, finans alanında dijital bir devrim yaratma ve ekonomik paradigmaların değişimine katkı sağlama potansiyeline sahip oldukları görülmektedir ve serbest akan bir ticaret sistemi yaratarak serbest piyasaların yapısını dönüştürebilirler. Kripto paraların temelinde bulunan dağıtılmış muhasebe teknolojileri, finansal süreçleri güçlendirebilir. Uzun vadede, bu teknolojilerin derinleşme potansiyeli vardır; ancak kesin olan şudur ki kripto paraların büyüyen kullanımına rağmen, bu potansiyel faydaları gerçekleştirmek için yasal zemine/ilerlemeye, kurumsallaşmaya ihtiyaç duyulmaktadır. Kurumsallaşma, bankaların, aracı kurumların, borsaların, ödeme sağlayıcıların ve küresel finansal hizmetler ekosistemindeki diğer yapıların kripto para pazarına katılımlarıyla mümkün olabilecektir. Bu katılımın kripto paralar için güven ve ölçek oluşturmak adına gerekli bir adım olduğu düşünülmektedir.

\subsubsection{Altcoin Kavramı}

Dünya kp borsasının değer ve işlem hacmi olarak açık ara lideri olan Bitcoin dışındaki tüm kripto paraların genel ifadesi olarak kullanılan altcoin terimi, alternatif kripto paralar olarak düşünülebilir. Kavram "alternate cryptocoins"in kısaltmasıdır, yani Bitcoin'e alternatif kripto paraları ifade etmek için kullanılmaktadır. Bir anlamda Bitcoin'i taklit etme amacında oldukları söylenebilir; ancak şu ana kadar onun yerini alabilecek ya da Bitcoin'in değerini aşan herhangi bir kripto para söz konusu olmamıştır.

Altcoinler, Bitcoin'in başarısından sonra başlatılan alternatif kripto para birimleridir. Genellikle kendilerini Bitcoin'e daha iyi bir alternatif olarak yansıtırlar. Eşler arası ilk dijital para birimi olan Bitcoin'in başarısı, birçok $\mathrm{kp}$ projesinin Bitcon'in izini sürmesine sebep olmuştur. Böylece birçok altcoin; Bitcoin'in sahip olduğu sınırlamaları ve sorunlu olduğu iddia edilen özelliklerini 
giderme ve rekabet avantajı sağlama vaadiyle Bitcoin'in yeni sürümleri olarak ortaya çıkmıştır (Frankenfield, 2019). Altcoin kavramı; "Bitcoin'den esinlenerek oluşturulmuş alternatif dijital para birimleri” (Yang, 2018), "kolektif bir terim olarak Bitcoin'in alternatif versiyonları yani Bitcoin'in türevleri” (Vigna, 2017) olarak da tanımlanmaktadır. Bu terminoloji, Bitcoin'in orijinal şifreleme para birimi olduğu ve daha sonra geliştirilen diğerlerinin Bitcoin'e alternatif dijital paralar olarak kabul edildiği fikrinden ileri gelmektedir.

Altcoinler; Bitcoin'in temsil ettiği fikri geliştirmeyi amaçlayan, Bitcoin'in yapısını (blockchain teknolojisini) kullanan, adını değiştirip, bazı küçük düzeltmeler ve yeni eklentiler yaparak yepyeni bir dijital para birimi gibi lanse edilen kripto paralardır (Rawat ve Tiku, 2017: 2493). Altcoinler farklı özellikler taşıyabilirler, örneğin bir altcoin hızlı işlem özelliği ile bir diğeri ise gizli işlem özelliği ile öne çıkabilir. Bu özellikler ise, altcoinlerin hacimleri ve varlığı üzerinde doğrudan etkilidir. Altcoinlerin piyasa hacimleri \%40-60 arasında değişmekte olup birçok altcoin piyasada tutunamamakta ve yok olabilmektedir. Altcoinlerin ortaya çıkışında temelde iki nedenden bahsedilebilir. Bunlardan ilki, kripto paraların iyileştirilme isteği; diğeri ise üretiminin Bitcoin'e kıyasla kolay bir şekilde yapılmak istenmesidir. Kolay bir şekilde üretilebilme altcoinlerin ortaya çıkmasında oldukça önemli bir faktördür. Bitcoin madenciliğinin oldukça zor olması, üretimi daha kolay olan altcoinleri teşvik etmiştir (Sistemkoin, 2019).

Altcoins terimi, Bitcoin olmayan tüm kripto para birimleri anlamına gelmektedir ve her bir altcoin, Bitcoin'i geliştirmeyi amaçlayan şifreleme işlemleridir. Kripto para dünyasındaki altcoinlerin sayısı üç bine yaklaşmaktadır; ancak bunların hepsi kp borsalarında işlem görmemektedir. Bitcoin'in ortaya çıkışından sonra dört bin adet altcoin üretilmiştir; fakat bazıları (1200'e yakını) kp piyasasında tutunamamıştır. Burada Bitcoin'in en yakın takipçileri konumunda olan ve dünya kp borsalarında işlem gören bazı altcoinlere değinilecektir.

Kripto paraları listelemek için belli kriterleri olan, verileri her beş dakikada bir güncellenen, 15 dilde ve 32 ülkeye içerik sağlayan ve kripto paraların piyasa hacim, değer ve fiyatlarının öğrenilebildiği CoinMarketcap verilerine göre (CoinMarketCap, 2019b): Bitcoin'e en yakın altcoinlerin ilk yirmi sıralamasında yer alan kripto paraların (piyasa değerine göre) sıralaması şu şekildedir: Ethereum (ETH), Ripple (XRP), Bitcoin Cash, Litecoin (Bitcoin'e en yakın rakip olarak görülmektedir), Tether, EOS, Binance Coin, Bitcoin SV, Stellar, Cardano, Monero, TRON, UNUS SED LEO, Huobi Token, Dash, IOTA, Ethereum Classic, Tezos, Chainlink ve NEO.

Altcoinlerin çoğu, Bitcoin tarafindan sağlanan temel çerçeve üzerine kuruludur; ancak farklı çalışma kanıtı algoritmaları, farklı yöntemler ve kullanıcı anonimliğini artırmak için uygulama geliştirmeleri de dahil olmak üzere çeşitli işlemsel varyasyonlarla Bitcoin'den farklı oldukları görülmektedir. Altcoinler ile ilgili en önemli konulardan biri de fiyat dalgalanmalarıdır. Altcoinler, fiyatları kolaylık ve sıklıkla manipüle edilebilen, dolayısı ile fiyat manipülasyonuna daha fazla yatkın olan dijital paralardır ve söz konusu volatilite yüksekliğinden dolayı yüksek riskli yatırımlar oldukları göz önünde bulundurulmalıdır.
Kripto para birimleri, şu an erken kabul aşamasındadır ve muhtemelen klasik küresel finansal sistemler için en yıkıcı teknolojiler olarak görülmektedir. Gelecekte kripto paraların daha fazla benimsenip benimsenmemesi daha da önemli bir konu olacaktır. Dünya çapında para alışverişini ve hatta alışverişin yapısını değiştiren, dönüştürücü bir teknoloji olabileceğinden ciddi anlamda takip edilmeye değer bir alan olduğu düşünülmektedir. Kripto paraların artan kullanımı, eğer küresel pazar değişimlerine entegre bir şekilde bağlanabilirse; Dolar ve Euro gibi, kripto paraların da bazıları uluslararası çapta serbestçe hareket edebilir ve küresel ticareti teşvik eden bir ortam yaratabilir.

\subsection{Blok Zinciri (Blockchain) Teknolojisi}

Son on yıldır blok zinciri teknolojisi büyük ilgi görmekte ve farklı sektörlerden birçok fikir ve projeyi tetiklemektedir. Perakende sektöründen seracılığa kadar birçok farklı sektör, müşteri ilişkileri süreçlerinde ya da üretim zincirinde matematiğe güvenmek istemektedir. Blok zinciri teknolojisi de iş süreçlerinde insandan matematiğe geçişi/güveni temsil ediyor olabilir; ancak şu an için blok zinciri teknolojisinin birçok sektörde teknik inceleme aşamasında olduğu ve akademik çalışmaların da ağırlıklı olarak kripto para birimleri çevresinde yürütüldüğü görülmektedir. Bununla birlikte, finans endüstrisi blockchain konseptinin birincil ve yaygın kullanıcısı olarak öne çıkmaktadır.

Mulligan'a (2017) göre; blok zinciri teknolojisi çoğunlukla Bitcoin ve diğer kripto paralar ile bağdaştırılsa da çok daha fazlasını ifade etmektedir. Bitcoin ve diğer kripto paralardan daha büyük bir potansiyele sahip bir teknolojidir. Finansal alanın ötesinde eski nesil dijital teknolojiye dayanan veri ve bilgileri, aracıları da aradan çıkararak daha hızlı ve daha güvenli bir biçimde toplayan, değiştiren, dönüştüren bir yapısı vardır. Bir blok zinciri, ortak çıkarları olan güvenilmez taraflara, merkezi bir otoriteye gerek olmadan, kalıcı, değişmez ve şeffaf bir değişim ve işlem kaydı oluşturma imkânı sunmaktadır (s. 9-10).

Blok zinciri teknolojisine yönelik eleștiriler, yalnızca bu teknolojinin en iyi bilinen uygulamasının kripto para birimleri olduğu gerçeğinden değil, aynı zamanda özellikle bu sektördeki önemli işlem verimsizlikleri ve büyük bir maliyet sorunundan da kaynaklanmaktadır. Bir blok zinciri, bir bloğun çoklu işlemlerinden, bir veri paketleri zincirinden (bloklar) oluşan veri kümeleridir. Blok zinciri, her bir ek blok tarafından genişletilir ve bu nedenle işlem geçmişinin eksiksiz bir kaydını temsil eder. Bloklar, kriptografik araçlar kullanılarak ağ tarafından doğrulanabilir. İşlemlere ek olarak, her blok bir zaman damgası, önceki bloğun karma değeri ve söz konusu karma değerin doğrulanması için rastgele bir sayı içerir. Bu konsept tüm blok zincirinin ilk bloğa kadar bütünlüğünü sağlar ve bütünlüğe de "genesis bloğu" denir. Bloktaki karma değerler benzersizdir ve hatanın/yanlışın ya da sahtekârlığın etkili bir şekilde önlenmesini sağlar; çünkü zincirdeki bir bloğun değişiklikleri hemen ilgili hash (verilen girdiye özel/biricik üretilen çıktı) değerini değiştirir. Ağdaki düğümlerin çoğunluğu bir bloktaki işlemlerin geçerliliği ve bloğun geçerliliği hakkındaki uzlaşma mekanizması ile aynı ise blok zincire eklenebilir (Nofer vd., 2017: 183). Blok zincirinin bu yapıs1; bir anlamda fikir birliği mekanizması yaratır. Ağın çoğunluğunun oluştuğu bir süreç olan bu durum bir tür mutabakattır ve böylece dünyanın her yerinden insanlar 
internet aracılı̆̆ bağlanabilir, güvenebilir ve farklı varlık türlerini birebir değiştirebilir duruma gelmektedir (Swanson, 2015: 22).

Kripto varlıklardan olan dijital paralar, kriptografi ve dağıtılmış muhasebe/dağıtık defter teknolojisindeki (DLT: distributed ledger technology) gelişmeler sayesinde mümkün olan dijital değerlerin sunumlarıdır. Blockchain teknolojisi, sistemi yönetmek için merkezi bir yapıya, kurum ya da otoriteye (örneğin bir merkez bankasına) ihtiyaç duymadan kayıt oluşturmak ve tutmak için dağıtılmış defterlerin kullanılmasina olanak taniyan bir sisteme dayanmaktadır. Kripto varlıklar kendi hesap birimlerinde gösterilir ve aracı olmadan eşler arası/uçtan uca transfer edilebilir (Munoz vd., 2018: 5-6). Şekil 1 ve 2'de, merkezi ve blok zincirine dayalı dağıtılmış muhasebe sistemleri arasındaki temel farklar yer almaktadır (IMF, 2016: 20):

Şekil 1: Merkezi Ödeme/Muhasebe Sistemi

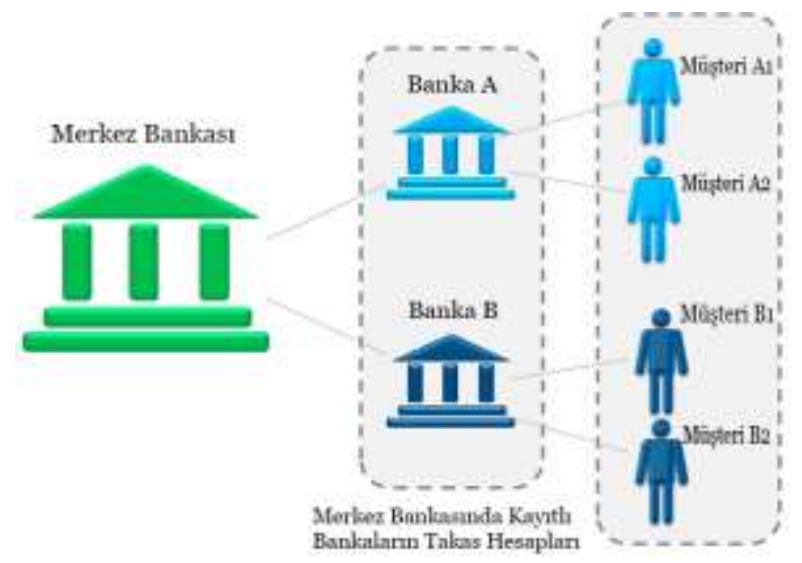

Şekil 1'de ifade edilen merkezi ödeme sisteminde Müşteri A1'den müşteri B1'e olan varlık transferi ya da ödeme şu şekilde gerçekleşmektedir: Öncelikle para, müşteri A1'in A bankasındaki hesabından alınır/düşülür. Ardından merkez bankası parayı A bankasının hesabından B bankasına taşır. B bankası müşteri $\mathrm{B} 1$ 'in hesabına parayı aktarır ve $\mathrm{A}$ ve $\mathrm{B}$ bankaları, sırasıyla A1 ve B1 müşterileri için işlem defteri tutar. Merkez bankası, işlemleri mükerrer ödeme ve dolandırıcılığa karşı koruma amaçlı denetledikten sonra onaylar, böylece transfer gerçekleşmiş olur. $\mathrm{Bu}$ sistemde merkez bankaları, tarafları hem koruma hem de bankalar arası işlemlerin merkezi kaydını tutma işlevini yerine getirmiş olmaktadır.

Şekil 2: Blok Zinciri (Blockchain) Dağıtık Muhasebe Sistemi

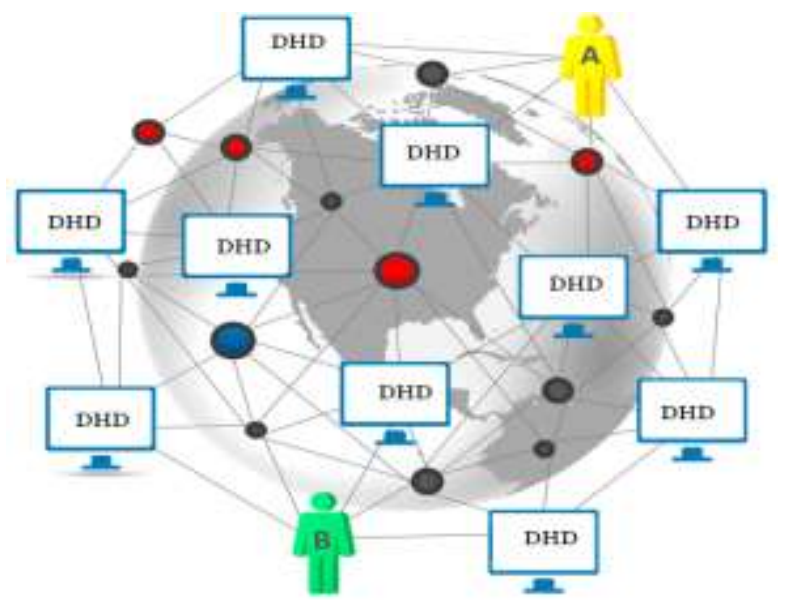

Şekil 2'de kripto paraların sahip olduğu blok zinciri alt yapısına dayanan dağıtık hesap defterleri (DHD) sisteminin söz konusu olduğu yapıda ise A tarafindan ya da kişisinden B'ye varlık transferi ya da ödeme şu şekilde gerçekleşmektedir: İşlem, ağa bilgi işlem kaynağı sağlayan ve madenciler (miners) olarak adlandırılan çok sayıda madenci tarafından gerçekleştirilir. İşlem kayıtlarının (defterler) kopyaları ağdaki birden fazla bilgisayarda saklanır ve herkes tarafından görülebilir. Dağıtılmış hesap defteri (DHD), bir bilgisayar ağında karşılıklı olarak paylaşılan ve senkronize edilen verisel düğümlerden (node) oluşan bir veri tabanıdır. İşlem kayıtları (defterler) da bu düğümlerde tutulur ve herkes tarafindan görülebilir niteliktedir. İşlemler taraflar arasında birebir, herhangi bir üçüncü taraf ya da aracı olmadan (merkez bankası, bankalar veya ödeme şirketleri gibi) gerçekleşir ve madenciler tarafindan doğrulanır.

Blockchain bir dağıtılmış defter türüdür ve Bitcoin ve birçok kripto paranın altında yatan teknolojidir. Blockchain, çevrimiçi olarak akranlar arasında ödemeler gibi değerlerin paylaşılmasını sağlayan yazılım destekli bir kamu defteridir. Daha da önemlisi, blockchain, bankalar veya ödeme şirketleri gibi üçüncü taraf aracılardan geçmeye gerek kalmadan bilgilerin paylaşılmasını ve varlıkların transferini sağlar. Adından da anlaşılacağı gibi, zincirlerle birbirine bağlanmış bloklardan yapılmıştır ve her blok, blok zinciri üzerinde yer alan işlemlerin geçmişinin küçük bir bölümünü depolar (Dadonaite, 2019).

Özünde, blok zincirleri, internet erişimi olan dünyanın herhangi bir yerinde faaliyet gösteren bireysel kullanıcılar arasında işlemlerin güvenli bir şekilde değiştirilmesine, kaydedilmesine ve yayınlanmasına izin veren, bilgisayar yazılımına kodlanmış sayıların dijital dizileridir. Blok zincirleri, belirli derecelerde ve belirli seviyelerde maskelenen dijital şifreleme teknolojilerini içerir. Sistem içerisindeki içerik, kişisel kullanıcıların kimlikleriyle değiştirilemez. Önceden kodlanmış adım adım talimat dizisi, karmaşık matematiksel denklemleri çözme ve kullanıcıların ağları içindeki işlemlerin geçerliliği konusunda bir fikir birliğine varmasını sağlar. Daha sonra periyodik olarak doğrulanmış işlemleri veri kümeleri veya "bloklar" halinde toplar. Sırayla birbirine bağlı olan bu bloklar, kullanıcıların ve takas edilen belirli içeriklerin gizliliğini korur ve işlemlerin kalıcı bir kaydını tutan daha büyük blok zinciri veri tabanlarını oluşturur. Blockchain, hepsinin kaydını tutan dijital, merkezi olmayan bir defter ve eşler arası bir ağda gerçekleşen ve bilgilerin şifrelemesini sağlayan işlemler bütünü olarak da ifade edilebilir.

Büyüyen ve yaygınlaşan blok zincir teknolojisi ve ona dayalı faaliyetlerin genişliği, ortaya çıkan teknolojinin uygulanmasına ve sonuçlarına ilişkin hem ütopyacı vaatleri hem de distopyan korkuları tetikleyecek nitelikte görünmektedir.

\section{Kripto Paralara Yönelik Handikap ve Eleştiriler}

Kripto para birimlerinin kullanım ve yaygınlığı arttıkça eleştirilerin şiddet ve sayısında da artış söz konusu olmaktadır. En başta, ciddi ekonomik tasarım kusurlarına sahip olduğu (Auer, 2019: 3); egemen para gibi ölçeklenemeyeceği, tıkanmaya eğilimli olduğu ve ödeme kesinliklerinin sorunlu olduğu ileri sürülmektedir. Kişisel 
bilgilerin gizliliği ve müşteri haklarının korunması gibi şüphelerin de hala giderilmediği görülmektedir. Teknik olarak her bir kripto para kullanıcısının gerçekleştireceği her bir işlem, blockchain bloklarına birkaç yüz bayt eklemekte, bu durum da zamanla dosya boyutlarında birikmelerin olmasına sebep olmaktadır. Bitcoin blok zinciri içerisinde, nispeten düşük sayıda işlem yapılsa bile sadece Bitcoin'in işleyebildiği bu dosya, birkaç yüz gigabaytlık dosya boyutuyla sonuçlanmaktadır. Böylece Bitcoin'in gerçek ulusal ödeme sistemleri tarafından ele alınan işlem numaralarını işlemesiyle, dosya büyüklükleri haftalar içerisinde on binlerce gigabaytın üzerine çıkabilecektir.

Kripto para işlemlerinin gerektirdiği dijital alan ihtiyaçları yani dosya hacimleri devasa boyutlara ulaşabileceğinden, limit üstü durumlarda sistem tıkanabilir, sayısal istikrarsızlıklar ortaya çıkabilir ve para transferlerinde ücret artışları ve uzun bekleme süreçleri ortaya çıkabilir. Bu durum Carstens (2018) tarafindan; "maksimum blok büyüklüğüne ulaşmak”, "işlenmemiş işlemlerin birikmesi”, "sayıların ağırlığı" veya "tıkanıklık" olarak tarif edilmektedir (s. 5). Dosya hacim problemi şöyle de açıklanabilir; eğer bir kripto para biriminin kullanıcısı ne kadar fazla olursa, yukarıda bahsedilen sistem tıkanıklığı o kadar yüksek olabilir. Ödeme kesinlikleri ile ilgili sorunlar ise bazı ödemelerin zaman zaman geriye dönük geçersiz k1lınması, karşıt yönden ise görünüşte ödeme defterine girmiş olan işlemlerin bile söz konusu olabilmesidir. Yani yapılmış olan kripto para ödemeleri gerçekleşmemiş, yapılmamış olanlar da kayıtlı olarak dağıtık defterde yer alabilmektedir. Teknik açıdan bakıldığında, bitcoin gibi kripto para birimlerinin ödeme kesinliğini garanti edemez olabilmesi söz konusudur.

Diğer bir eleştiri ise kripto para birimlerinin güven sorunudur. Bir para biriminin değerine güven duymak, ilgili para biriminin tedarikinin bir protokol tarafından önceden belirlenmesini gerektirir. Aksi takdirde, düzensiz olarak tedarik edilir ve hızlı bir şekilde değer kaybedebilir. Bu nedenle, herhangi bir dalgalanma, talep değerlemedeki değişikliklere dönüşür. Bitcoin de dahil, ki altcoinlerde dalgalanma daha hızlı ve şiddetli olabilmektedir, kripto para birimlerinin değerlerindeki aşırı derecede iniş ve çıkışlar (pump and dump) bu istikrarsızlığın temel göstergeleridir. Bu fiyat istikrarsızlığı/sapmaları ve şiddetli dalgalanmalar hedef kitlelerde belirgin bir güven kaybını öne çıkarmaktadır. Bu duruma ek olarak ve daha vahim bir biçimde, birçok altcoin dönem dönem piyasaya sürülmüş ve başarısız kripto para denemeleri olarak adeta dijital para mezarlığında yerini almıştır. Sonuç olarak, kripto para piyasası önemli değer dengeleme problemleri ile karşı karşıya kalmaktadır.

Diğer bir olumsuz taraf ise kripto paraların perakende alımsatım işlemlerinde ve gerçek ödeme işlemlerinde kullanmasının son derece sinırlı olmasıdır. 2017 y1lı son çeyreğinde Bitcoin ve diğer kripto paraların neredeyse tavan fiyatlarda işlem gördüğü ve kripto para yatırımlarının zirve yaptığı dönemde dahi, perakende ödeme işlemlerinde kullanımı piyasa yatırım hacmine göre çok sınırlı kalmıştır. Bitcoin'in ödemelerde kullanımı 2017 yılı son çeyreğinin ilk ayı olan ekim ayında en yüksek miktara ulaştığı ve ardından hızlıca düştüğü kaydedilmiştir. Ekim ayı toplam perakende ödeme miktarı, ABD doları cinsinden ifade edilen "aylık küresel işlem” hacmi 400 milyon dolarla sınırlı kalmıştır. Bu miktar her ay sadece bir kredi kartı şirketi olan VISA tarafından işlenen 500 milyar ABD Doları işlem hacmi ile karşılaştırıldığında son derece küçük bir miktardır (Carstens, 2018: 4-6). Birçok tüccar, başlangıçta bir ödeme aracı olarak Bitcoin'i kullanmasına rağmen, pratikte, yavaş, pahalı ve güvensiz olduğu ortaya çıktığında hızlı bir şekilde kullanmaktan vazgeçmiştir. Yine Expedia.com gibi pek çok çevrimiçi site, çeşitli sorunlar ve sınırlamalar nedeniyle Bitcoin veya başka herhangi bir kripto para birimini ödemelerde kabul etmediğini duyurmuş ve kripto para ödemelerini durdurmuştur (chainanalysis.com, 2018).

Bir başka handikap ise yine kripto paralara ve kripto para borsalarına karşı güveni zedeleyen bir unsur olarak, kripto para birimlerinin adem-i merkeziyetçi bir yapı sunması ve anonimliğinin sonucu olarak yasa dışı faaliyetlere oldukça elverişli olmasıdır. Hırsızlığa karşı da son derece hassas bir yapıları vardır. Sürekli çeşitli kripto para borsalarından hırsızlık haberleri gelmektedir. Bu anonim yapının yasa dışı etkinlik boyutları ise sermaye kontrollerinden ya da vergilerden kaçınmak, terörizme finans sağlamak, uyuşturucu ve kara para aklama hatta seçim süreçlerinde siyasi manipülasyonları finanse etme işlemlerine kripto paraların konu olması ve bu amaçlarla kullanılmasıdır. Kripto para birimlerinin anonimlik ve merkezi olmama özelliği yasa dışı amaç ve eylemlere elverişli bir yapı sunmaktadır; çünkü yasa dışı iş ve işlemlerde bulunmak isteyenler için neredeyse mükemmel bir koruma sağlamaktadır.

Foley, Karlsen ve Putnins'in 2018 y1lında gerçekleştirdiği ve kripto para birimleri ile ne oranda yasa dışı faaliyetin finanse edildiğinin tespit edilmesinin amaçlandığı çalışma sonucunda; Bitcoin kullanıcılarının yaklaşık dörtte birinin yasa dışı faaliyetlerde bulunduğu görülmektedir. Rakamsal olarak yılda yaklaşık 76 milyar dolarlık yasadışı faaliyetin, ABD ve Avrupa yasadışı uyuşturucu pazarı ölçeğine yakın olan bir miktarda, bitcoin (bu da toplam bitcoin işlem hacminin \%46'sına tekabül etmektedir) içerdiği tahmininde bulunulmaktadır (Foley, Karlsen ve Putnins, 20018: 1-3). Bitcoin işlemlerinin neredeyse yarısının yasadış1 faaliyetlerle ilişkili olması, (ki altcoinlerdeki yasa dışı faaliyetlere ait işlem oranının ne kadar olduğu tespit edilememektedir, ancak daha yüksek olması olasıdır), kripto paraların illegal bir araca dönüştüğünü ve denetimsiz dijital piyasalarda e-ticaret üzerinden kara para aklama faaliyetlerini tetiklediğini göstermektedir.

\section{Yöntem}

Niğde Ömer Halisdemir Üniversitesi öğrencilerinin kripto para $(\mathrm{kp})$ birimlerini bilme ve kullanma düzeylerini belirlemenin amaçlandığı bu çalışmada üniversite öğrencilerine çalışmanın amacına uygun olarak anket uygulanmıştır. Bir veri toplama aracı olarak anket, katılımcıların belirli bir konuda düşünce, tutum ve davranışlarını, daha önce belirlenmiş bir sırada ve yapıda oluşturulmuş sorulara dayalı olarak elde etmeyi sağlamaktadır. Anket yoluyla elde edilen veriyi istatistiksel ve matematiksel analizden geçirmek mümkündür. Bununla birlikte anket çok sayıda kişiye ulaşılması gerektiğinde ideal bir veri toplama aracıdır (Gürbüz ve Şahin, 2016: 179).

Çalışmanın evrenini Niğde Ömer Halisdemir Üniversitesi öğrencileri oluşturmaktadır. Araştırmacının erişim kolaylığı, finansal ve zamansal sinırlılıklar nedeniyle 
Niğde Ömer Halisdemir Üniversitesi evren olarak belirlenmiştir. Ancak evrenin tamamında çalışmanın süre ve maliyet açısından elverişli olmaması dolayısıyla örneklem alınması yoluna gidilmiş ve farklı evrenler için kabul edilebilir örneklem büyüklükleri tablosu (Gürbüz ve Şahin, 2016: 132) referans alınarak 400 kişi (öğrenci) ile anket yapılmasına karar verilmiştir. Niğde Ömer Halisdemir Üniversitesinde 2018-2019 akademik yılında 28.681 öğrenci öğrenim görmüştür. ${ }^{1}$ Bu rakam dikkate alındığında ilgili tabloda \%95 güvenilirlik oranı asgari örneklem sayısının 379 olması gerektiği belirtilmektedir. Dolayısıyla anket uygulamasının yapıldığı kişi sayısı \%95 güven oranını karşılamaktadır. Uygulama, NÖHÜ Eğitim, İktisadi İdari Bilimler, İletişim ve Mühendislik fakültelerinde yapılmıştır. Bu nedenle bu çalışma, bu dört fakülteden ankete katılan 400 kişi ile sınırlıdır, dolayısıyla çalışmanın evrene genelleme niteliği yoktur. $\mathrm{Bu}$ çalışma üniversite öğrencileri kapsamında gerçekleştirildiğinden amaçlı örneklem alma tekniği kullanılmış, dolayısıyla yalnızca üniversite öğrencilerine anket uygulanmıştır. Ankete katılım gönüllülük esasına dayanmaktadır. Ankete 222 erkek, 178 kadın öğrenci katılmıştır.

Kripto para birimlerinin bilinirlik ve kullanılırlık düzeylerine ilişkin daha önce yapılmış bir çalışma bulunmadığından bu yönde önceden geliştirilmiş bir anket formu da bulunmamaktadır. Anket formunda yer alan her bir madde, çalışmanın amacına uygun olarak Niğde Ömer Halisdemir Üniversitesi İktisadi ve İdari Bilimler Fakültesi ve İletişim Fakültesi'nden iki öğretim üyesinin uzman görüşü alınarak hazırlanmıştır. Hazırlanan form, kapsam ve görünüş geçerliliği açısından formun birlikte hazırlandığ 1 iki uzman ile birlikte, ayrıca NÖHÜ İktisadi ve İdari Bilimler Fakültesi ve Mühendislik Fakültesi'nden birer uzman olmak üzere farklı iki öğretim üyesi tarafından da incelemeye tabi tutulmuştur. Hazırlanan 22 soruluk ön test, her bir fakülteden 25 'er olmak üzere 100 öğrenciye uygulanmış, yapılan madde güçlük ve ayırt edicilik değerlerinin analiz edilmesi sonucunda madde güçlük değeri 40'ın altında olan 4 soru anket formundan çıkarılmıştır. Anket formunda öncelikle öğrencilerin yaş1, cinsiyeti ve fakültelerini öğrenmeye yönelik demografik sorular sorulmuş, sonrasında ise çalışmanın amacına uygun olarak kapalı uçlu 18 soru sorulmuştur. Bu sorulardan 17 tanesi tercih belirleme sorusudur. 16 tanesi iki seçenekli (evet/hayır), 1 tanesi ise 1-4 arası bir seçeneğin tercih edilmesine yöneliktir. Anket sorularından biri katılımcıların hangi kripto para birimlerini bildiklerini ölçmek amacıyla sınıflayıcı sistemleştirme ${ }^{2}$ ile hazırlanmış, böylece katılımcıların birden fazla seçeneği işaretlemesine olanak sağlanmıştır.

Kesin verilerin elde edilmesi amaciyla hazırlanan anket formu 18.03.19-22.03.19 tarihleri arasında uygulanmıştır. Toplam 400 kişi ile yüz yüze anket yapılmış ve 400 tanesi veri olarak değerlendirilmiştir. Anket formlarıyla elde edilen veriler, Statistical Package for the Social Sciences (SPSS) 15 programında sayısallaştırılmış, elde edilen tablolar çalışmanın amacı doğrultusunda değerlendirilmiştir. Katılımcıların demografik özellikleri ve kripto paralar ile ilgili bilgi ve tutumlarının dağılımı görmek amacıyla frekans analizi; katılımcıların kripto paraları bilme durumuna göre $\mathrm{kp}$ ile ilgili bilgi ve tutumları arasında, verilen cevaplar (evet/hayır) açısından ve cinsiyet ile fakülte değişkenleri bağlamında anlamlı bir fark olup olmadığını görmek amacıyla da ki-kare testi yapılmıştır.

\section{Bulgular ve Yorumlar}

Bu bölümde öncelikle katılımcıların demografik özellikleri ve kripto paralar ile ilgili bilgi ve tutumlarının dağılımına, sonrasında katılımcıların bildikleri kripto paraların dağılımına yer verilmiştir. Katılımcıların kripto paraları bilme durumuna göre $\mathrm{kp}$ ile ilgili bilgi ve tutumlarının karşılaştırılmasının ardından cinsiyet ve fakülte değişkenlerine göre karşılaştırma yapılmıştır.

Anket sorularının iç tutarlılığının belirlenmesi için yapılan güvenilirlik analizi sonucunda Cronbach's $\alpha=.869$ çıkmıştır. $\mathrm{Bu}$ değer ölçeği oluşturan maddelerin iç tutarlılık güvenilirliğini göstermektedir. Ölçekteki maddeler arasında iç tutarlılık değeri kabul edilebilir değer olan 0.70 'ten yüksektir.
${ }^{1}$ http://www.ohu.edu.tr/oidb/sayfa/ogrenci-sayilari, Erişim Tarihi: 07.09.2019.

${ }^{2}$ Kapalı uçlu sorularda katılımcıya sunulan seçeneklerin sistemleştirilmesinde kullanılan sınıflayıcı sistemleş,tirmede, bir sorunun birbirinden bağımsız yanıt seçenekleri arasından bir ya da birkaçının seçilmesi öngörülmekte ve bu seçeneklerin konuları ve içerikleri ne olursa olsun hepsi eşdeğerli sayılmaktadır,

http://www.megep.meb.gov.tr/mte_program_modul/moduller_pdf/Biçimin e\%20Göre\%20Sorular.pdf, Erişim Tarihi: 07.09.2019. 
Tablo 1. Katılımcıların demografik özellikleri ve kripto paralar ile ilgili bilgi ve tutumlarının dağılımı $(\mathrm{n}=400)$

\begin{tabular}{|c|c|c|}
\hline Değişkenler & Sayı & Yüzde \\
\hline \multicolumn{3}{|l|}{ Cinsiyet } \\
\hline Erkek & 222 & 55,5 \\
\hline Kadın & 178 & 44,5 \\
\hline Yaş (yıl) & \multicolumn{2}{|c|}{$\begin{array}{l}\text { Ort } \pm \text { SS: } 21 \pm 2, \text { Ortanca: } 21 \\
\text { En Küçük: } 18 \text {, En Büyük: } \\
30\end{array}$} \\
\hline \multicolumn{3}{|l|}{ Fakülte } \\
\hline Eğitim & 100 & 25,0 \\
\hline İletişim & 100 & 25,0 \\
\hline İşletme & 100 & 25,0 \\
\hline Mühendislik & 100 & 25,0 \\
\hline $\begin{array}{l}\text { İnternet üzerinden yapılan alışverişe } \\
\text { güvenme }\end{array}$ & 276 & 69,0 \\
\hline İnternetten alışveriş yapma & 336 & 84,0 \\
\hline Kripto paraları bilme & 155 & 38,8 \\
\hline Kripto para madenciliğini bilme & 87 & 21,8 \\
\hline $\begin{array}{l}\text { Kripto para madenciliğinin nasıl } \\
\text { yapıldığını bilme }\end{array}$ & 49 & 12,3 \\
\hline Kp olarak maaş yatmasını isteme & 49 & 12,3 \\
\hline Herhangi bir kp sahibi olma & 26 & 6,5 \\
\hline $\begin{array}{l}\text { Kpların tek para birimi olmasını } \\
\text { isteme }\end{array}$ & 246 & 61,5 \\
\hline Satoshi Nakamoto’yu duyma & 74 & 18,5 \\
\hline \multicolumn{3}{|l|}{$\begin{array}{l}\text { Türkiye'de kp madenciliğinde } \\
\text { çalışan sayısı tahmini }\end{array}$} \\
\hline $0-100$ & 79 & 19,8 \\
\hline $100-10000$ & 126 & 31,5 \\
\hline $10000-50000$ & 102 & 25,5 \\
\hline $50000-250000$ & 93 & 23,3 \\
\hline Blockchain teknolojisini duyma & 72 & 18,0 \\
\hline $\begin{array}{l}\text { Kripto yatırımları bankalardan daha } \\
\text { güvenli bulma }\end{array}$ & 44 & 11,0 \\
\hline $\begin{array}{l}\text { Gelecekte kpların ulusal para yerine } \\
\text { kullanılacağını düşünme }\end{array}$ & 147 & 36,8 \\
\hline Kp ile alışveriş yapma & 21 & 5,3 \\
\hline Resmi kp olsa kullanma durumu & 193 & 48,3 \\
\hline $\begin{array}{l}\text { Gelecekte kpların yaygınlaşacağını } \\
\text { düşünme }\end{array}$ & 228 & 57,0 \\
\hline $\begin{array}{l}\text { Daha önce kp yatırımı yapma } \\
\text { durumu }\end{array}$ & 22 & 5,5 \\
\hline
\end{tabular}

Katılımcıların demografik özellikleri ve kripto paralar ile ilgili bilgi ve tutumlarının dağılımı Tablo 1'de verilmiştir. Katılımcıların kripto paraları bilme ve kullanma alıșkanlıklarına yönelik genel bir değerlendirme yapıldığında şu sonuçlar ortaya çıkmıştır: Katılımcıların $\% 55$ 'i erkek, yüzde 44,5'i kadın ve yaş ortalaması $21 \pm 2$ yıldır. Araştırmaya eğitim, iletişim, işletme ve mühendislik fakültelerinden 100'er kişi katılmıştır.

Katılımcıların \%69,0’u (n=276) internet üzerinden yapılan alışverişe güvendiğini ve \%84,0’ü $(n=336)$ internetten alışveriş yapmış olduğunu beyan etmiştir. Katılımcıların $\% 38,8$ 'i (n=155) kripto paraları, \%21,8'i (n=87) kripto para madenciliğini, \%12,3'ü ( $\mathrm{n}=49)$ ise kripto para madenciliğinin nasıl yapıldığını bildiğini beyan etmiştir. \%12,3’ü ( $n^{=49)}$ maaşının kripto para olarak yatmasını isteyebileceğini, $\% 6,5$ 'i ( $\left.\mathrm{n}^{2} 26\right)$ ise herhangi bir kripto parası bulunduğunu bildirmiştir. Araştırmada katılımcıların \%61,5'i (n=246) kripto paraların tek para birimi olmasını istemektedir. \% 18,5'i (n=74) Satoshi Nakamoto'yu daha önce duymuş olduğunu belirtmiştir.

Katılımc1ların \%18,0’i (n=49) blockchain teknolojisini duymuş, \%11,0'i $\left(\mathrm{n}^{=44}\right)$ kripto para yatırımlarını bankalardan daha güvenli bulmakta, \%36,8'i $\quad\left(n^{=} 147\right)$ gelecekte kripto paraların ulusal para yerine kullanılacağını düşünmekte ve \%5,3’ü $(n=21)$ kripto para ile daha önce alışveriş yapmıştır. Katılımcıların \%48,3'ü $\left(n^{=} 193\right)$ resmi kripto para olması durumunda kullanabileceğini, \%57,0'si $(n=228)$ gelecekte kripto paraların yaygınlaşacağını düşündüğünü, \%5,5'i $(n=22)$ ise daha önce kripto para yatırımı yaptığını beyan etmiştir.

Tablo 2. Katılımcıların bildikleri kripto paraların dağılımı $(\mathrm{n}=400)$

\begin{tabular}{clll}
\hline Değişken & Sayı & Yüzde & Kişi Yüzdesi \\
\hline Kripto Paralar & & & \\
\hline Bitcoin & 386 & 64,2 & 96,5 \\
\hline Litecoin & 65 & 10,8 & 16,3 \\
\hline Ethereum & 59 & 9,8 & 14,8 \\
\hline Ripple & 32 & 5,3 & 8,0 \\
\hline EOS & 30 & 5,0 & 7,5 \\
\hline IOTA & 29 & 4,8 & 7,2 \\
\hline Toplam & 601 & 100,0 & 150,3 \\
\hline
\end{tabular}

Tablo 2'de katılımcıların bazı kripto paraları bilme durumlarının dağılımı verilmiştir. Buna göre katılımcıların sirasıyla en sik Bitcoin $(\% 96,5)$, Litecoin $(\% 16,3)$ ve Ethereum $(\% 14,8)$ kripto paralarını bildiği saptanmıştır. Bu sonuçlar göstermektedir ki katılımcıların çoğu birden fazla kripto para birimini bilmektedir. 
Tablo 3. Katılımcıların kripto paraları bilme durumuna göre kp ile ilgili bilgi ve tutumlarının karşılaştırılması $(n=400)$

\begin{tabular}{|c|c|c|c|c|}
\hline \multirow[b]{3}{*}{ Değişkenler } & \multicolumn{4}{|c|}{ Kripto Para Nedir Bilme } \\
\hline & \multicolumn{2}{|c|}{ Evet } & \multicolumn{2}{|c|}{ Hayır } \\
\hline & $\mathrm{n}$ & $\% *$ & $\mathrm{n}$ & $\% *$ \\
\hline \multicolumn{5}{|c|}{ Kp madenciliğini bilme } \\
\hline Evet & 44 & 28,4 & 5 & 2,0 \\
\hline Hayır & 111 & 71,6 & 240 & 98,0 \\
\hline \multicolumn{5}{|c|}{ Kp olarak maaş yatmasını isteme } \\
\hline Evet & 36 & 23,2 & 13 & 5,3 \\
\hline Hayır & 119 & 76,8 & 232 & 94,7 \\
\hline \multicolumn{5}{|c|}{ Herhangi bir kp sahibi olma } \\
\hline Evet & 24 & 15,5 & 2 & 0,8 \\
\hline Hayır & 131 & 84,5 & 243 & 99,2 \\
\hline \multicolumn{5}{|c|}{$\begin{array}{l}\text { Kpların tek para birimi olmasını } \\
\text { isteme }\end{array}$} \\
\hline Evet & 109 & 70,3 & 137 & 55,9 \\
\hline Hayır & 46 & 29,7 & 108 & 44,1 \\
\hline \multicolumn{5}{|c|}{ Satoshi Nakamoto'yu duyma } \\
\hline Evet & 53 & 34,2 & 21 & 8,6 \\
\hline Hayır & 102 & 65,8 & 224 & 91,4 \\
\hline \multicolumn{5}{|c|}{ İnternetten kp ile alışveriş yapma } \\
\hline Evet & 145 & 93,5 & 191 & 78,0 \\
\hline Hayır & 10 & 6,5 & 54 & 22,0 \\
\hline \multicolumn{5}{|c|}{ Blockchain teknolojisini duyma } \\
\hline Evet & 53 & 34,2 & 19 & 7,8 \\
\hline Hayır & 102 & 65,8 & 226 & 92,2 \\
\hline \multicolumn{5}{|c|}{$\begin{array}{l}\text { Kripto yatırımları bankalardan } \\
\text { daha güvenli bulma }\end{array}$} \\
\hline Evet & 39 & 25,2 & 5 & 2,0 \\
\hline Hayır & 116 & 74,8 & 240 & 98,0 \\
\hline \multicolumn{5}{|c|}{$\begin{array}{l}\text { Gelecekte kpların ulusal para } \\
\text { yerine kullanılacağını düşünme }\end{array}$} \\
\hline Evet & 88 & 56,8 & 59 & 24,1 \\
\hline Hayır & 67 & 43,2 & 186 & 75,9 \\
\hline \multicolumn{5}{|c|}{ Resmi kp olsa kullanma durumu } \\
\hline Evet & 101 & 65,2 & 92 & 37,6 \\
\hline Hayır & 54 & 34,8 & 153 & 62,4 \\
\hline \multicolumn{5}{|c|}{$\begin{array}{l}\text { Gelecekte kpların } \\
\text { yaygınlaşacağını düşünme }\end{array}$} \\
\hline Evet & 118 & 76,1 & 110 & 44,9 \\
\hline Hayır & 37 & 23,9 & 135 & 55,1 \\
\hline \multicolumn{5}{|c|}{$\begin{array}{l}\text { Daha önce kp yatırımı yapma } \\
\text { durumu }\end{array}$} \\
\hline Evet & 22 & 14,2 & - & - \\
\hline Hayır & 133 & 85,8 & 245 & 100,0 \\
\hline
\end{tabular}

*Sütun Yüzdesi

$\mathrm{P}<0,01$

Katılımcıların kripto paraları bilme durumuna göre $\mathrm{kp}$ ile ilgili bilgi ve tutumlarının karşılaştırılması Tablo 3'te verilmiştir. Buna göre araştırmada $\mathrm{kp}$ bilme durumu ile $\mathrm{kp}$ madenciliğini bilme, kp olarak maaş yatmasını isteme, herhangi bir kp sahibi olma, kpların tek para birimi olmasını isteme, Satoshi Nakamoto'yu duyma, internetten $\mathrm{kp}$ ile alışveriş yapma, Blockchain teknolojisini duyma, kp yatırımlarını bankalardan daha güvenli bulma, gelecekte kpların ulusal para yerine kullanılacağını düşünme, resmi kp olması durumunda kullanma, gelecekte kpların yaygınlaşacağını düşünme ve daha önce kp yatırımı yapma durumu ile istatistiksel olarak anlamlı bir fark saptanmıştır $(p<0,01)$. Kripto paraların ne olduğunu bilen katılımcılarla $\mathrm{kp}$ madenciliğini bilme, kp olarak maaş yatmasını isteme, herhangi bir kp sahibi olma, kpl arın tek para birimi olmasını isteme, Satoshi Nakamoto'yu duyma, internetten kp ile alıșveriş yapma, Blockchain teknolojisini duyma, kp yatırımlarını bankalardan daha güvenli bulma, gelecekte kpların ulusal para yerine kullanılacağını düşünme, resmi kp olması durumunda kullanma, gelecekte kpların yaygınlaşacağını düşünme ve daha önce kp yatırımı yapma durumunun, kpları bilmeyenler arasinda anlamlı bir farklılık olduğu görülmüştür.

Tablo 4. Katılımcıların cinsiyetine göre kp ile ilgili bazı bilgi ve tutumlarının karşılaştırılması $(\mathrm{n}=400)$

\begin{tabular}{|c|c|c|c|c|}
\hline \multirow{3}{*}{ Değişkenler } & \multicolumn{4}{|c|}{ Cinsiyet } \\
\hline & \multicolumn{2}{|c|}{ Erkek } & \multicolumn{2}{|c|}{ Kadın } \\
\hline & $\mathrm{n}$ & $\% *$ & $\mathrm{n}$ & $\% *$ \\
\hline \multicolumn{5}{|l|}{ Kripto paraları bilme } \\
\hline Evet & 119 & 53,6 & 36 & 20,2 \\
\hline Hayır & 103 & 46,4 & 142 & 79,8 \\
\hline \multicolumn{5}{|c|}{ Kripto para madenciliğini bilme } \\
\hline Evet & 72 & 32,4 & 15 & 8,4 \\
\hline Hayır & 150 & 67,6 & 163 & 91,6 \\
\hline \multicolumn{5}{|c|}{ Kp olarak maaş yatmasını isteme } \\
\hline Evet & 30 & 13,5 & 19 & 10,7 \\
\hline Hayır & 192 & 86,5 & 159 & 89,3 \\
\hline \multicolumn{5}{|c|}{ Herhangi bir kp sahibi olma } \\
\hline Evet & 21 & 9,5 & 5 & 2,8 \\
\hline Hayır & 201 & 90,5 & 173 & 97,2 \\
\hline \multicolumn{5}{|c|}{$\begin{array}{l}\text { Kplerin tek para birimi olmasını } \\
\text { isteme }\end{array}$} \\
\hline Evet & 142 & 64,0 & 104 & 58,4 \\
\hline Hayır & 80 & 36,0 & 74 & 41,6 \\
\hline \multicolumn{5}{|c|}{ Satoshi Nakamoto'yu duyma } \\
\hline Evet & 56 & 25,2 & 18 & 10,1 \\
\hline Hayır & 166 & 74,8 & 160 & 89,9 \\
\hline \multicolumn{5}{|c|}{ İnternetten kp ile alışveriş yapma } \\
\hline Evet & 196 & 88,3 & 140 & 78,7 \\
\hline Hayır & 26 & 11,7 & 38 & 21,3 \\
\hline \multicolumn{5}{|c|}{ Blockchain teknolojisini duyma } \\
\hline Evet & 48 & 21,6 & 24 & 13,5 \\
\hline Hayır & 174 & 78,4 & 154 & 86,5 \\
\hline \multicolumn{5}{|c|}{$\begin{array}{l}\text { Kripto yatırımları bankalardan } \\
\text { daha güvenli bulma }\end{array}$} \\
\hline Evet & 34 & 15,3 & 10 & 5,6 \\
\hline Hayır & 188 & 84,7 & 168 & 94,4 \\
\hline \multicolumn{5}{|c|}{$\begin{array}{l}\text { Gelecekte kpların ulusal para } \\
\text { yerine kullanılacağını düşünme }\end{array}$} \\
\hline Evet & 93 & 41,9 & 54 & 30,3 \\
\hline Hayır & 129 & 58,1 & 124 & 69,7 \\
\hline \multicolumn{5}{|c|}{ Resmi kp olsa kullanma durumu } \\
\hline Evet & 123 & 55,4 & 70 & 39,3 \\
\hline Hayır & 99 & 44,6 & 108 & 60,7 \\
\hline \multicolumn{5}{|c|}{$\begin{array}{l}\text { Gelecekte kpların } \\
\text { yaygınlaşacağını düşünme }\end{array}$} \\
\hline Evet & 134 & 60,4 & 94 & 52,8 \\
\hline Hayır & 88 & 39,6 & 84 & 47,2 \\
\hline \multicolumn{5}{|c|}{$\begin{array}{l}\text { Daha önce kp yatırımı yapma } \\
\text { durumu }\end{array}$} \\
\hline Evet & 20 & 9,0 & 2 & 1,1 \\
\hline Hayır & 202 & 91,0 & 176 & 98,9 \\
\hline
\end{tabular}

*Sütun Yüzdesi

$\mathrm{P}<0,01$

Tablo 4'te katılımcıların cinsiyetine göre kp ile ilgili bazı bilgi ve tutumlarının karşılaştırılması verilmiştir. Buna göre araştırmada cinsiyet ile kripto paraları bilme durumu, $\mathrm{kp}$ madenciliğini bilme, herhangi bir $\mathrm{kp}$ sahibi olma, Satoshi Nakamoto’yu duyma, internetten kp ile alışveriş 
yapma, Blockchain teknolojisini duyma, kp yatırımlarını bankalardan daha güvenli bulma, gelecekte kpların ulusal para yerine kullanılacağını düşünme, resmi kp olması durumunda kullanma ve daha önce kp yatırımı yapma durumu arasında istatistiksel olarak anlamlı bir fark kaydedilmiştir $(\mathrm{p}<0,05)$. Erkeklerde $\mathrm{kp}$ bilme durumu, $\mathrm{kp}$ madenciliğini bilme, herhangi bir kp sahibi olma, Satoshi Nakamoto'yu duyma, internetten $\mathrm{kp}$ ile alışveriş yapma, blockchain teknolojisini duyma, kp yatırımlarını bankalardan daha güvenli bulma, gelecekte kp ların ulusal para yerine kullanılacağını düşünme, resmi kp olması durumunda kullanma ve daha önce kp yatırımı yapma durumu sıklığı kadınlara göre anlamlı düzeyde daha yüksek tespit edilmiştir. Çalışmada cinsiyetler arasında kp olarak maaş yatmasını isteme, kpların tek para birimi olmasını isteme ve gelecekte kpların yaygınlaşacağını düşünme durumu açısından ise istatistiksel olarak anlamlı bir fark görülmemiştir ( $p>0,05)$.

Tablo 5. Katılımcıların eğitim gördükleri Fakültelere göre kp ile ilgili bazı bilgi ve tutumlarının karşılaştırılması $(n=400)$

\begin{tabular}{|c|c|c|c|c|c|c|c|c|}
\hline & \multicolumn{8}{|c|}{ Fakülteler } \\
\hline & \multicolumn{2}{|c|}{ Eğitim } & \multicolumn{2}{|c|}{ İletişim } & \multicolumn{2}{|c|}{ İ̈BF } & \multicolumn{2}{|c|}{$\begin{array}{l}\text { Mühendi } \\
\text { slik }\end{array}$} \\
\hline & $\mathrm{n}$ & $\%$ & $\mathrm{n}$ & $\%$ & $\mathrm{n}$ & $\%$ & $\mathrm{n}$ & $\begin{array}{l}\% \\
*\end{array}$ \\
\hline \multicolumn{9}{|l|}{$\begin{array}{l}\text { Kripto } \\
\text { paraları bilme }\end{array}$} \\
\hline Evet & 27 & 27 & 49 & 49 & 17 & 17 & 62 & 62 \\
\hline Hayır & 73 & 73 & 51 & 51 & 83 & 83 & 38 & 38 \\
\hline \multicolumn{9}{|l|}{$\begin{array}{l}\text { Kripto para } \\
\text { madenciliğini } \\
\text { bilme }\end{array}$} \\
\hline Evet & 12 & 12 & 25 & 25 & 8 & 8 & 42 & 42 \\
\hline Hayır & 88 & 88 & 75 & 75 & 92 & 92 & 58 & 58 \\
\hline \multicolumn{9}{|l|}{$\begin{array}{l}\text { Kp olarak } \\
\text { maaş } \\
\text { yatmasını } \\
\text { isteme }\end{array}$} \\
\hline Evet & 11 & 11 & 17 & 17 & 8 & 8 & 13 & 13 \\
\hline Hayır & 89 & 89 & 83 & 83 & 91 & 91 & 87 & 87 \\
\hline \multicolumn{9}{|l|}{$\begin{array}{l}\text { İnternetten } \\
\text { alışveriş } \\
\text { yapma }\end{array}$} \\
\hline Evet & 80 & 80 & 92 & 92 & 70 & 7 & 94 & 94 \\
\hline Hayır & 20 & 20 & 8 & 8 & 30 & 30 & 6 & 6 \\
\hline \multicolumn{9}{|l|}{$\begin{array}{l}\text { Gelecekte } \\
\text { kpelerinyayg1 } \\
\text { nlaşacağını } \\
\text { düşünme } \\
\end{array}$} \\
\hline Evet & 59 & 59 & 66 & 66 & 42 & 42 & 61 & 61 \\
\hline Hayır & 41 & 41 & 34 & 34 & 58 & 58 & 39 & 39 \\
\hline
\end{tabular}

$\mathrm{P}<0,01$

Katılımcıların kripto paraya ilişkin tutumlarının fakülteler bazındaki dağılımı Tablo 5'te verilmiştir. Buna göre araştırmada öğrenim görülen fakülte ile kp bilme durumu, $\mathrm{kp}$ madenciliğini bilme, internetten $\mathrm{kp}$ ile alışveriş yapma ve gelecekte kpların yaygınlaşacağını düşünme durumu arasında istatistiksel olarak anlamlı bir fark saptanmıştır $(p<0,01)$. Mühendislik fakültesi öğrencileri diğer fakülte öğrencilerine göre kripto paraları ve kripto para madenciliğini anlamlı düzeyde daha fazla bilmekte ve daha sık internetten $\mathrm{kp}$ ile alışveriş yapmaktadır. İşletme fakültesi öğrencileri diğer fakülte öğrencilerine göre kpların gelecekte yaygınlaşacağına daha az inanmaktadır. Araştırmada öğrenim görülen fakülte ile $\mathrm{kp}$ olarak maaş yatmasını isteme durumu arasında ise istatistiksel olarak anlamlı bir fark saptanmamıştır $(\mathrm{p}>0,05)$.

\section{Sonuç}

Teknolojik gelişmeler parayı, ödeme ve yatırım sistemlerini, tüm finansal hizmetleri, finansal pazarları etkilemekte ve finansal birim ve aracılığın niteliğini ve ödeme biçimlerini de dönüştürmektedir. Para ile ilgili değişimler dünyadaki tüm insanları etkilediğinden kripto paralara yönelik ilgi her geçen gün artmaktadır. Paranın biçimi ile ilgili değișiklikler kullanıcılara birçok yarar ve avantaj sunmayı amaçlamakta; ancak bu yenilik ve avantajlar beraberinde yeni riskleri de getirmektedir. $\mathrm{Bu}$ noktada dijital paraların yararları ile risklerini dengelemek gerekmekte, dengelemek için de en iyi yöntem hızlı teknolojik değişimler karşısında daha proaktif olunarak hem olanakları keşfetmek hem de olası riskleri ortadan kaldıracak çözümleri üretebilmektir. Kripto paralar ile ilgili tasarım ve çözümler geliştikçe, fiyat istikrarı, ödeme ve yatırım güvenliği sorunları çözüldükçe, verimli ve esnek bir finansal sistem teşvik edilebilir.

Yeni teknolojiler, küresel ekonomik arenada malların, hizmetlerin ve varlıkların yapısında dönüşümsel etkilere neden olmaktadır. ABD'li bilim adamı ve fütürist Roy Amara'nın dediği gibi, genel olarak; "bir teknolojik yeniliğin teknolojideki etkisini abartma ĕgilimindeyiz" (PC Magazine, 2019). Teknolojik yenilik, memnuniyet ve heyecanla karşılanırken aynı zamanda kısa ve uzun vadede bu yeniliğin olası etki ve sonuçları da hafife alınmamalıdır. Söz konusu para kavramı olunca da iktisat yasalarına, bilgi birikimi ve sağduyuya dayanmak gerekmektedir.

Kripto varlıklarının makroekonomik istatistiklerde ele alınması, sınıflandırılması, ulusal ve uluslararası olarak incelenmeli ve kripto paraların kabul edilebilirliklerinin zemini, şartları ve sınırları ile ilgili çalışmalar yapılmalıdır. Kripto paraların gelişim ve rafine edilme sürecini kolaylaştırmak için ulusal ve uluslararası düzeyde daha fazlasının yapılabileceği düşünülmektedir. Bu doğrultuda, kripto paralar için ulusal ve uluslararası yetki makamlarının, yasa düzenleyicilerin yenilikçiliği boğmadan, ancak risk ve istismarları da uygun şekilde karşılayabilecek yöntem ve mevzuatları geliştirmeleri gerekmektedir.

Kripto para alanı hala çok yeni, hızla gelişen ve emekleme aşamasında olan bir yapıdadır. Bu nedenle gelecekteki yönünü ve önemini tam olarak tespit etmek mümkün değildir. Daha fazla araştırma ve analiz yapılabilecek açık bir alandir. $\mathrm{Bu}$ durumdan sebeple; bu makalede kripto paralar ve blockchain teknolojisi ile ilgili verilen bilgilerin, gelecekte nasıl geliştiğine bağlı olarak tekrar gözden geçirilmesi gerekebilir; çünkü kripto paralar gelişim aşamasındadır ve sürekli hızlı bir değişim geçirmektedir. Bununla birlikte kripto paraların kullanımının belirlenmesi ve kullanımın gelecekte nasıl değişeceğinin de takip edilmesi önem taşımaktadır. Bu bağlamda çalışmada Niğde Ömer Halisdemir Üniversitesi Üniversite öğrencilerinin kripto paraları bilme ve kullanma alışkanlığının belirlenmesi amaçlanmış olup çalışma Niğde Ömer Halisdemir Üniversitesi öğrencileri ile sınırlıdır. Araştırmaya katılan 400 öğrencinin \%38,8'inin kripto paraları biliyor olduğu belirlenmiştir. $\mathrm{Bu}$ veri üniversite öğrencilerinin sanal paralara olan ilgisinin çok da uzak olmadığının bir kanıtıdır. $\mathrm{Bu}$ bilinirliği öğrencilerin \%84'lük internet kullanımı ile 
değerlendirmek mümkündür. Bu oran NÖHÜ öğrencilerinin teknolojiye olan yatkınlığının üst seviyelerde olduğunu göstermektedir. Dolayısıyla öğrencilerin kripto paralar hakkındaki haberleri, gelişmeleri, süreçleri takip etme imkanlarının olduğu ya da farklı internet mecralarında kplar ile karşılaşma olasılıklarının yüksek olduğu düşünülmektedir.

Kripto para alışkanlıkları fakülte bazında irdelediğinde Mühendislik Fakültesi öğrencilerinin \%62'lik bir oranla kripto para bilinirliğinin diğer fakülte öğrencilerine göre daha yüksek olduğu görülmektedir. Mühendislik Fakültesi'ni \%49'luk bir dilimle İletişim Fakültesi izlemektedir. Eğitim Fakültesi ise \%27'lik bir oran ile üçüncü sırayı almaktadır. Fakülteler bazında dikkate değer diğer bir nokta İktisadi İdari Bilimler Fakültesi öğrencilerinin kripto para bilme ve kullanma durumlarının diğer fakültelere göre en düşük düzeyde olmasıdır. Fakültenin Bankacılık ve Finans, İktisat, İşletme, Maliye gibi ağırlıklı olarak para ile ilişkili bölümleri barındırmasına rağmen \%17'lik bir yüzde ile diğer fakültelerin gerisinde kalması beklenmedik bir durumdur. Bununla birlikte günümüzde kripto para temsilcileri, yorumcuları hatta kuruluşlarındaki grup başkanları İktisadi ve İdari Bilimler Fakültesi mezunu olduğu da dikkate alındığında çıkan sonuç üzerinde durulmaya değerdir.

Fakülteler bazında "kripto paranın yaygınlaşacağını düşünür müydünüz?" sorusuna gelen yanıtlardan alınan sonuçlara bakıldığında İIBF öğrencilerinin diğer fakültelerin öğrencilerine göre kripto paranın yaygınlaşacağını düşünme oranı düşük çıkmıştır. İletişim Fakültesi'nin ise diğer fakültelerin aksine \%66'llk bir oranla ileride kripto paranın yaygınlaşacağına inanan ve kripto paraya en fazla güveni olan fakülte olduğunu söylemek mümkündür. Maaşının kripto para olarak yatmasını isteyen öğrenci sayısının da en yüksek olduğu fakülte \%17'lik dilimle yine İletişim Fakültesi'dir.

Mühendislik öğrencilerinin de kripto paraya ilgisinin yoğun olduğu görülmektedir. Kp madenciliğini bilme oranı \%42 ile en yükssek olan fakültedir. Bununla birlikte en çok kp sahibi olan öğrenciler de Mühendislik Fakültesinde okumaktadır. İIBF, kripto para bilme ve güven düzeyi en düşük fakülte olmasına karşın en çok kripto para sahibi olan sıralamasında 2. sırada yer almaktadır. Cinsiyet bazında incelediğimizde veriler gösteriyor ki kadınların \%20,2 si, erkeklerin ise \%53,6's1 kripto para hakkında bilgi sahibidir. Bununla birlikte erkek öğrencilerin 21'i, kadın öğrencilerin ise 5 kripto para sahibidir. Dolayısıyla toplamda kadın ve erkek sadece 26 kişinin kripto paraya sahip olması kripto para bilinirliğine göre kullanım düzeyinin düşük olduğunu göstermektedir. Bunun nedeninin öğrencilerin henüz kripto paraya tam olarak güvenemedikleri, kripto para teknolojisinin özellikle Türkiye'de henüz yeterince bilinmiyor oluşu ya da kripto paranın geleceğinin henüz tam olarak öngörülemiyor oluşundan kaynaklandığını söylemek mümkündür.

Çalışmanın yöntem bölümünde de belirtildiği gibi bireylerin kripto para birimlerini bilme ve kullanma düzeyinin belirlenmesine yönelik daha önce yapılmış bir çalışma ve anket uygulaması bulunmamaktadır. Bu nedenle bu çalışmada kullanılan anket formu uzman görüşü alınarak araştırmacı tarafından geliştirilmiştir. Bundan sonra yapılacak benzer çalışmalarda anket formunun aynen ya da geliştirilerek farklı örneklem gruplarına uygulanması da mümkündür. Dolayısıyla bu çalışma benzer çalışmalara öncülük etmesi açısından literatüre katkı sağlayacaktır. Bununla birlikte bu çalıșma Niğde Ömer Halisdemir Üniversitesi'nde okuyan ve ankete katılan 400 öğrenci ile sınırlıdır. Katılımcı sayısının arttırıldığı, toplumun geneline yayınlan daha geniş kapsamlı çalışmalar yapmak da mümkündür.

\section{Kaynakça}

Aksoy, E. E. (2018). Bitcoin: Paradan Sonraki En Büyük İcat - Blockchain Teknolojisi ve Altcoinler. İstanbul: Abaküs Kitap Yayın Dağıtım Hizmetleri.

Auer, R. (2019). Beyond the Doomsday Economics of "Proof-Ofwork" in Cryptocurrencies, the Technology and the Economics of Decentralised Trust in Bitcoin and the Blockchain. Monetary and Economic Department, 765, January.

Carstens, A. (2018). Money in A Digital Age: 10 Thoughts, General Manager, Bank for International Settlements. Lee Kuan Yew School of Public Policy, Singapore, 15 November 2018.

Chainalysis Inc. (20018). Report: Bitcoin Retail Payment Transactions, https://chainalysisblog.webflow.io/reports/report-the-changingnature-of-cryptocrime. New York, D.C., Copenhagen, London. (Erişim Tarihi: 30.05.2019).

Campbell-Verduyn, M. (2018): Bitcoin, Crypto-coins, and Global Anti-Money Laundering Governance. Springer Science+Business Media B.V. Crime, Law and Social Change 69(2), 283-305, https://doi.org/10.1007/s10611-017-9756-5.

CoinMarketCap, (2019a). Monthly Volume Rankings (Currency) - Total Market Capitalization, https://coinmarketcap.com/currencies/volume/m onthly/; https://coinmarketcap.com/tr/charts/. (Erişim Tarihi: 08.07.2019).

CoinMarketCap, (2019b). Top 100 Cryptocurrencies by Market Capitalization: All Cryptocurrencies Top 100/full list, https://coinmarketcap.com/. (Erişim Tarihi: 23.09.2019).

Dadonaite, B. (2019). 10 Questions About Blockchain: What Is Blockchain, Where Is It Used, and Will It Become Mainstream?, Phys.org Science X Network, Home- Technology - Computer Sciences, $\quad$ https://phys.org/news/2019-05blockchain.html. (Erişim Tarihi: 30.07.2019).

Demertzis, M. ve B. Wolff, G. (2018). The Economic Potential and Risks of Crypto Assets: Is A Regulatory Framework Needed? Bruegel Policy Contribution Issue, 14, 1-36.

DeVries, P. D. (2016): An Analysis of Cryptocurrency, Bitcoin, and the future. International Journal of Business Management and Commerce, 1(2), 1-10.

Foley, S. and Karlsen, J. R. ve Putnins, T. J. (2018). Sex, Drugs and Bitcoin: How Much Illegal Activity Is Financed Through Cryptocurrencies? Review of 
Financial Studies, 1-63, http://dx.doi.org/10.2139/ssrn.3102645.

Frankenfield, J.(2019). Investing Cryptocurrency Altcoin, What Is Altcoin? https://www.investopedia.com/terms/a/altcoin.asp. (Erişim Tarihi: 18.08.2019).

Gürbüz, S ve Şahin, F. (2016). Sosyal Bilimlerde Araştırma Yöntemleri. Ankara: Seçkin Yayınları.

http://www.ohu.edu.tr/oidb/sayfa/ogrenci-sayilari, (Erişim Tarihi: 07.09.2019).

International Monetary Fund (IMF), (2016). Virtual Currencies And Beyond: Initial Considerations. IMF Staff Discussion Note, Monetary and Capital Markets, Legal and Strategy and Policy Review Departments, SDN/16/03, Washington.

Leopold, R. ve Vollmann, P. (2018). Cryptographic Assets And Related Transactions: Accounting Considerations Under IFRS, In Depth. A Look At Current Financial Reporting Issues PwC: PricewaterhouseCoopers, London, https://www.pwc.com/gx/en/auditservices/ifrs/publications/ifrs-16/cryptographicassets-related-transactions-accountingconsiderations-ifrs-pwc-in-depth.pdf. Tarihi: 30.07.2019).

Menon, R. (2018). Crypto Tokens - The Good, The Bad and The Ugly. Speech given by the Managing Director of the Monetary Authority of Singapore at Money 20/20, Singapore. March.

Milli Eğitim Bakanlığı, (2012). Halkla İlişkiler ve Organizasyon Hizmetleri Alanı, Biçimine Göre Sorular 342pr00042, http://www.megep.meb.gov.tr/mte_program_modu 1/moduller_pdf/Biçimine\%20Göre\%20Sorular.pdf. (Erişim Tarihi: 07.09.2019).

Mulligan, C. (2017). Blockchain - A Brief Overview. Imperial College London, https://www.eiseverywhere.com/file_uploads/b4d7 22450d854c8b9fdaf14823c49a0c_MULLIGAN_B lockchain-brief-overview.pdf. (Erişim Tarihi: 18.08.2019).

Munoz, C. S, Dinenzon, M. Venkat, J., Ramirez, J. C. M., Dippelsman, R. ve Razin, T. (2018). Treatment of Crypto Assets In Macroeconomic Statistics. ThirtyFirst Meeting of the IMF Committee on Balance of Payments Statistics, BOPCOM-18/11, Washington, D.C. 1-30.

Nofer, M., Gomber, P., Hinz, O. and Schiereck, D. (2017). Blockchain, Springer Fachmedien Wiesbaden, 59(3), s. 183-187, http://dx.doi.org/10.1007/s12599-017-0467-3.

Nagaraj, K. Hunter, C. ve Caplain, J. (2018). Institutionalization of Cryptoassets: Cryptoassets
Have Arrived. Are You Ready for Institutionalization? International Cooperative, NDPPS 775054, USA.

PC Magazine and PC PCMag.com, Pcmag Digital Encyclopedia, (2019). Definition of Amara's Law, https://www.pcmag.com/encyclopedia/term/3770 1/amara-s-law. (Erişim Tarihi: 25.05. 2019).

Polat, M. ve Akbıyık, A. (2019). Sosyal Medya ve Yatırım Araçlarının Değeri Arasındaki İlişkinin İncelenmesi: Bitcoin Örneği. Akademik İncelemeler Dergisi, 14(1), 443-462.

Rawat, R. ve Tiku, N. (2017). Introduction of Bitcoin With Comparison to Other Alternative Coins Called Altcoin. International Research Journal of Engineering and Technology (IRJET), 4(6), 2490-2494.

Sistemkoin, (2019). Altcoin Nedir ve Neden Ortaya Çıkmıştır? Altcoin Yatırım Tavsiyeleri Nelerdir? Sistemkoin, Blok-Talk-Learn, https://blog.sistemkoin.com/altcoin-nedir/. (Erişim Tarihi: 25.07. 2019).

Swanson, T, (2015). Consensus As A Service: A Brief Report on the Emergence of Permissioned, Distributed Ledger Systems, http://www.ofnumbers.com/wpcontent/uploads/2015/04/Permissioneddistributed-ledgers.pdf. (Erişim Tarihi: 28.07. 2019).

Wikimedia Foundation, Inc., Wikipedia, (2019a). Article: White Paper In Government and In Business to Business Marketing. https://en.wikipedia.org/wiki/White_paper. (Erişim Tarihi: 20.05. 2019).

Wikimedia Foundation, Inc., Wikipedia, (2019b). Madde: Kriptografi: Kriptografik Sistemlerin Esaslar1, https://tr.wikipedia.org/wiki/Kriptografi. (Erişim Tarihi: 30.06. 2019).

Tilborg, H.C.A.V. (2000). Fundamentals of Cryptology: A Professional Reference and Interactive Tutorial, Classical Cryptosystems. Boston/Dordrecht/London: Kluwer Academic Publishers.

Vigna, P. (2017). Which Digital Currency Will Be the Next Bitcoin? The Wall Street Journal, https://www.wsj.com/articles/which-digitalcurrency-will-be-the-next-bitcoin-1513679400 (Erişim Tarihi: 18.08.2019).

Yang, S. (2018). Want to Keep Up With Bitcoin Enthusiasts? Learn The Lingo. The Wall Street Journal, https://www.wsj.com/articles/want-tokeep-up-with-bitcoin-enthusiasts-learn-the-lingo1517394601. (Erişim Tarihi: 18.08.2019). 